\title{
VISIBILITY OF INVISIBLE: COVID-19 AND NEPAL-INDIA MIGRATION
}

\author{
Jeevan Baniya ${ }^{* 1}$, Sadikshya Bhattarai', Vibhav Pradhan ${ }^{3,}$ Binay \\ Jung Thapa ${ }^{3}$ \\ ${ }^{1}$ Assistant director, Social Science Baha, and Faculty, DIRD TU, Kathmandu Nepal \\ ${ }^{2}$ Senior Research Associate, Social Science Baha, Kathmandu, Nepal. \\ ${ }^{3}$ Research Associate, Social Science Baha, Kathmandu, Nepal. \\ *Corresponding author: jbaniya@gmail.com
}

\begin{abstract}
India remains the preferred destination for Nepali migrant workers. There is a freedom of movement and work to citizens of both the countries without the need of passport or visa requirements. This paper studies the impact of COVID-19 on Nepali migrants in India by employing a mixed method research approach. The imposition of nationwide lockdowns in both India and Nepal has resulted in multiple forms of impacts on migrants, revealing a complicated cross-border dynamics. Sudden enforcement of restrictive measures including lockdowns, while necessary, adversely triggered vulnerabilities and precarity onto millions of Nepali migrants in India. The lack of political and legal recognition and inadequate state policies towards social protections worsened the magnitude and severity. While immediate relief measures and safe return is necessary in the short term, it suggests revising their foreign policy, development and social security policies to address the adverse drivers that Nepali migrants have faced.
\end{abstract}

Keywords: COVID-19 - migration - livelihoods - social security.

\section{INTRODUCTION}

Migration of Nepali from Nepal to India has a long history. Nepali were recruited into the armies of Sikh ruler Ranjit Singh and in various other states in the early $19^{\text {th }}$ century, into British army after 1885 and into the Indian Army after 1947 (Sharma \& Thapa 2013). The 'Peace and Friendship Treaty' of 1950 between Nepal and India allows the citizens of Nepal and India to move and work freely across the border without any passport or visa requirement. 
Although, Nepali have increasingly migrated to Gulf Cooperation Council(GCC) countries and Malaysia for work (Kansakar 2003; Khatiwada 2014), India remains one of the major destinations for employment. There is no accurate data about Nepali in India because of the freedom of people to move across the open borders (as many as 144) as well as lack of data collection system in place. According to the Nepal Labour Force Survey (NLFS) 2017/18, there are approximately 1.2 million Nepali migrants in India who migrated for work, education, training, to join families etc. The survey also demonstrates that most of them are in unskilled or low skilled work in retail, manufacturing, construction or service and sales sectors. Other studies also suggest that they are working in the formal sector, as soldiers in Indian army, or the public and also in the private sectors (Adhikari and Gurung 2009, Sharma \& Thapa 2013). Nepal also has hugely benefited economically in the form of remittances received from the Nepali migrants to India.

Unlike in the context of other major destination countries, there are no legal mechanisms to govern and protect Nepali who go to India for work. The 1950 Indo-Nepal Treaty of Peace and Friendship is the only instrument that governs cross-border mobility but it has no reference to the labour migration as such (Sharma \& Thapa 2013). Nepali work in India without any visa, work permits or other official documents. Except some who possess Adhar Card and/or Ration Card, most of them are outside of the safety nets, hence, work in vulnerable situations. Amidst the Coronavirus Disease 2019 (COVID-19) pandemic followed by enforcement of strict lockdowns, the Nepali in India seemed to have been severely affected. This article attempts to identify various impacts of the pandemic on Nepali migrants, and discuss implications of the current experiences on protection of migrant workers in the context of Nepal-India migration. More specifically, it addresses these questions:

- What are the experiences of Nepali migrants, including ill-treatment and stigmatisation?

- What are the challenges faced by Nepali migrants in being returned to Nepal?

- What have been the efforts of both the Government of Nepal (GoN) and Government of India in facilitating the mass exodus of migrant workers from India to Nepal? 
- What are the pressing issues Nepali migrants face from here on after returning to Nepal?

- What are the key lessons in regards to bilateral relations and protection of migrants, to be learned from these experiences?

\section{Governing migrants in pandemic: General discussions}

Migrants are in the epicentre of the current pandemic. Most economic migrants who are in economic and social situations force them to migrate for foreign employment and fall further into the cruel trap of crisis (Mawadza 2008). There is a wider consensus that migrants are one the most vulnerable groups of people in the world who are regularly subject to violence, mistreatment, exploitation and trafficking, long working hours, unpaid or delayed wages, lack of access to insurance, health care, legal and other assistance in the destination countries (McCormack, Larsen and Husn 2015, Song 2015, Akaha 2018). Kelly and Wadud (2012) even argued that the pandemic-induced migration in itself is a crisis as it leads to labour deficiency in the destination countries and a burden of unemployment.

Migrants are vulnerable to any disaster or calamitous situations and face countless hardships during such times (IOM 2017). They continue facing barriers to accessing information, resources and opportunities which reduces their ability to prepare for and cope with global calamities such as COVID-19 (MICIC 2016). In addition with the loss of jobs and livelihoods, their vulnerabilities and precarity is further exacerbated when they, as an outsider, are ill-treated, stigmatised, excluded and discriminated in countries of destination and are perceived as nothing more than a labour (Sammadar 2020). Protection of migrants in the current crisis situation becomes challenging also due to a lack of data and impacts of any given disaster on the migrant workers (Guadagno 2015).

Acknowledging the multi-dimensional aspects of migration (Betts 2011) discourses increasingly has moved beyond the traditional paradigms of 'national interests' and 'national security' and increasingly it is looked from political economy perspectives (Ghosh 2010) or from transnational and global governance (Geiger 2020, Koser 2010, Munck 2008). Emphasis has been put on protection of people including migrants and their fundamental freedoms and dignity in pervasive and critical situations like the current pandemic through ensuring personal, community, political, economic, food, health and environmental security (UNDP 1994, Commission on 
Human Security 2003). For the protection of migrants, a secure legal status and protection including access to basic services and right to return etc. Have been recognised globally such as in Convention on the Protection of the Rights of All Migrant Workers and Members of their Families 1990, International Covenant on Civil and Political Rights (ICCPR), Charter of the United Nations, Universal Declaration of Human Rights (UDHR) and Global Compact for Migration (GCM), which makes all the states responsible to ensure these regardless of their legal status (Song 2015). Some call the new governance the 'humane' and right based governance approach (Piper 2017).

\section{METHODS}

The research draws primarily on a study, 'COVID-19 and Nepali Labour Migrants: Impacts and Responses' carried out by Centre for the Study of Labour and Mobility (CESLAM), Social Science Baha from 13 April 2020 to 29 May 2020. The rapid assessment employed mixed-method to analyse the impacts of Covid-19 on the external and internal migrant workers of Nepal. In order to get a current estimate of numbers of Nepali migrants in India, raw data from Nepal Labour Force Survey (NLFS) 2017/18 were analysed. Furthermore, various national and international news publications and news portals in English and Nepali languages such as Kantipur Daily, The Kathmandu Post, Nagarik, Nepali Times etc., from December, 2020 till the end of May, 2020 were reviewed, to identify various impacts of the COVID-19 pandemic on Nepali migrants. Furthermore, insights on the issues including recommendations for protection, repatriation, rehabilitation and integration of Nepali migrants were obtained from consultation meetings and group discussions with relevant stakeholders representing academics and researchers, migrant workers' networkers, international organizations, and human rights organizations. Stakeholders included representatives from People's Forum, Aprabasi Mahila Kamdar Samuha (AMKAS), United Nation Development Program (UNDP), International Labour Organization (ILO), World Health Organization (WHO), Pourakhi Nepal, Kantipur Daily, Social Science Baha, Pravasi Nepali Coordination Committee (PNCC), Helvetas, International Organization for Migration (IOM), UNWOMEN, Equidem, World Bank, Hamro Samman, Winrock International, Women's Rehabilitation Centre (WOREC), Safer Migration Project (SaMI), The Asia Foundation, United States Agency for International Development (USAID), Far East Overseas Nepali Association (FEONA), Asian Human Rights and Culture Development Forum, National Environment and Equity 
Development Society (NEEDS) Nepal. Likewise, secondary sources from World Bank and Nepal Rastra Bank (NRB) were utilised to estimate remittance flow from India to Nepal. The data obtained from the primary and secondary sources were categorized into broader topics and then distributed into specific themes which then was analysed and interpreted. Moreover, relevant statistical data obtained were interpreted as per the themes defined during the study. The fact that the study was carried out in the context of pandemic and within a limited period of time, it should be understood in the same context.

\section{RESULTS}

\section{Nepali-India migration trends}

India is the most popular destination for Nepali migrants. According to the National Population Census, $93.1(375,196)$ percent of Nepali emigrants migrated to India in $1981,89.2$ per cent $(587,243)$ in 1991, 77.3 per cent $(589,050)$ in 2001 and 37.6 per cent $(722,255)$ in 2011 (Kansakar 2003, Khatiwada 2014). The more recent NLFS 2017/18 data shows that there are approximately 1.2 million migrants in India. Among them, approximately one million migrated for work-related reasons in 2017/18 and around half a million migrated for 'Service/Job' while another 300,000 migrated to look for jobs. Of those who migrated for work related or other reasons, 13 per cent or approximately 160,000 were female. NLFS 2017/18 also shows that migrants in India who migrated for work-related reasons are primarily engaged in unskilled or low skilled work mostly in retail, manufacturing, construction or service sectors. Further, more than 300,000 migrants were engaged in elementary occupations such as street vendors (except food), helpers, and cleaners, labourers in the manufacturing, construction, and agriculture sectors among others. Another 30,000 were working in the service and sales sector which includes work related to travel, housekeeping, catering, personal care, as well as sale of goods in wholesale or retail shops or similar establishments. Similar trend is visible at the province level, where most of the migrants were engaged in elementary occupation and service and sales work in India.

\section{Impacts on Nepali economy, employment and livelihoods}

The impact of COVID-19 has been felt globally and is expected to have huge ramifications on macro and microeconomic levels; disrupting the livelihoods of people, especially the migrant workers. The impact of 
COVID-19 is going to be more severe on low- and middle-income countries, and it will particularly affect vulnerable groups like daily wage workers, labour migrants and those workers in informal employment and with no or limited access to social protection nets (ILO 2020).

According to the estimates by the World Bank, Nepal's remittance contribution to national GDP has ranged between 25 to 31 percent over the decades, and is expected to have a decline in the coming years (Ratha, De, Kim, Plaza, Seshan, \& Yameogo 2020). India has remained one of the major sources of remittance in Nepal after Qatar and Saudi Arabia contributing NPR 128.5 million in the fiscal year 2018/19 (Nepal Rastra Bank 2020). But Nepal is estimated to experience around 14 per cent decline in remittance in the next fiscal year (Ratha, De, Kim, Plaza, Seshan, \& Yameogo 2020). Similarly for Nepal, which already has a high (11.4\%) unemployment and high poverty rate (18.7\% of the total population), the impact on the economy will mean that millions of Nepali will face stress on their jobs and incomes, and face food insecurity (MoLESS 2018, GoN 2020).

A striking number of Nepali travel to India to find work every day (as per NLFS 2017/18). Most of the Nepali migrants in India are daily wage workers who lack any kind of financial safety net to absorb the impact of COVID-19 crisis. They and their families' livelihood depends on them being able to earn daily through a variety of manual labour work. However, during the months of ensuing lockdown implemented by the GoN and the Indian government to stop the spread of COVID-19, their livelihood have been obstructed causing hunger. (Baniya, Bhattarai, Thapa, \& Pradhan 2020). Furthermore, the migrant returnees who were stranded at different border points had to face sudden disruption of jobs and in their only income sources, making them and their families in Nepal financially impaired for facing future social and economic complications created by the pandemic

Migration has been a lifeline for Nepali economy for a very long time. With a sharp decline in the remittance and uncertainty looming in the domestic economy and job opportunities, it will have significant effects on individuals and families including the migrants (Baniya, Bhattarai, Thapa \& Pradhan 2020). The outbreak has impacted the employment of over 1.2 million Nepali in India in one way or another, a million of which being exclusively for work. 


\section{Nepali migrants stranded at Nepal-India border}

Since the imposition of nationwide lockdown in India and in Nepal due to COVID-19 from the fourth week of March 2020, many Nepali workers returned to the country only to be denied access into Nepal. As a result, thousands of Nepali migrant workers were stranded at different locations along the border and kept at quarantine facilities in India. However, there were many attempts to breach the quarantine on both sides as people were arrested and detained while crossing the border by other means such as swimming across the Mahakali River which indicates the complications in open border management (Baniya, Bhattarai, Thapa \& Pradhan 2020; Nepal, Baniya. \& Kshetri 2020).

Initially, at the beginning of April, many who managed to reach Nepal's border were barred from entry to Nepal and were accommodated at the temporary quarantine facilities built on the no man's land by India at Indo-Nepal border in Nepalgunj (Baniya, Bhattarai, Thapa \& Pradhan 2020). The inflow of migrants stranded at the border increased further, as India slowly eased the restrictions on cross border movement starting from April, 2020.

\section{Experiences and challenges in quarantines, temporary shelters, and travel to homes}

By April 2020, thousands of Nepali citizens, primarily daily wage migrant workers, were stranded in India and they requested the Government of Nepal (GoN) and the Embassy of Nepal in New Delhi to create an environment for their return home. Furthermore, most Nepal is stranded and quarantined in India desperately wanted to go home to Nepal and urged the GoN to take swift actions. Due to lack of vehicle movement in different Indian states, many Nepali migrants have taken to walking to reach Nepal. For many, it has taken days to reach the Nepal border on foot. Moreover, the uncertainty of getting food, water or any medical assistance on the way that made the journey even more daunting. The returnees showed disappointment in the incompetence of GoN in providing basic provisions such as food and water for the returnees even after being placed in quarantines in Nepal (Nepal, Baniya \& Kshetri 2020). The health professionals at the borders sent the returnees to the quarantines where they were kept for two weeks after just temperature screening. There also were cases of Nepali migrants 
dying on the journey or at the Nepal-India border due to various health reasons to which the GoN remained indifferent at that time.

\section{Experiences and risks of ill-treatment and stigmatisation}

With the rise in the number of coronavirus infections around the world, there has been an increase in the cases of social stigmatisation of various individuals and communities even triggering a number of incidences of xenophobic responses around the world (Bauomy 2020). The stigmatisation is generally based on misinformation, rumours and negative narratives. Also as per a rapid assessment conducted by Pravasi Nepali Coordination Committee Kathmandu (PNCC) based on 447 cases obtained through online forms submitted by the Nepali migrants from 16 different countries of destination revealed that many Nepali migrants were having psychological problems during COVID-19 (PNCC 2020). Nepal's Muslim population too has had to face a degree of stigma as a result of the outbreak. Instigated by rumours, and based off of India's 'Tablighi Jamaat' media coverage, Muslims and people living in the Terai in particular were singled out for the initial spread of the virus in India-bordering towns and districts, including Banke, Kailali, Parsa, Bara, Rupandehi, Kapilvastu, as well as significant number of cases in Udayapur which was related to the Tablighi Jamaat case (Sijapati 2020).

\section{Government's efforts to support migrants}

The GoN started the repatriation of Nepali stranded at the borders only after Nepal's Supreme Court's interim order on April 7, 2020 to bring all the Nepali citizens stranded at the Indian border to Nepal. To manage the massive influx of Nepali migrants, quarantine facilities were established on both Nepali and Indian sides.

With a scenario that COVID-19 has presented, authorities of Nepal and India have agreed to look after each other's citizens stuck at the border during the lockdown. Both Nepal and Indian governments also agreed to keep the people in quarantine as precaution. But the same level of support and entry to Nepal was not available to the hundreds of thousands of Nepali migrants who still remained stranded in various parts of India due to the lockdown and unavailability of air and land transportation to Nepal from various parts of India. 
Within Nepal, various financial provisions have also been designed to ease the shock of COVID-19 on the migrant workers. The Ministry of Labour, Employment and Social Security (MoLESS) has allocated Rs. 4.8 billion for the Prime Minister Employment Programme (PMEP), of which Rs. 2 billion were transferred to the local level government levels in the month of February 2020. The government is planning to create jobs for returning migrants through the PMEP as a response for the impact of COVID-19 on migrant workers (Baniya, Bhattarai, Thapa \& Pradhan 2020).

\section{DISCUSSIONS}

The findings of this study have shed light on the current state of preparedness of GoN to deal with situations of emergencies like the impact of COVID-19, and the state of social security in Nepal.

Firstly, the findings suggest that the Nepal-India boundaries are fluid and historically multidimensional in terms of socio-economic, cultural and labour ties. Hence, rather than dealing with the issues of cross border migration as the issue of limited national interest or from the perspectives of securitisation of migration (Ibrahim 2005, Wohlfeld 2014), it will be mutually beneficial to address these issues in more humane and human security perspectives. The diplomacy between the two countries should not just be limited within the spheres of economic and political interests, but also to be extended to the protection and promotion of interests and wellbeing of the Nepali migrant workers in India.

Secondly, the lack of precise data on Nepali working in India makes it very difficult for Nepal as well as India to plan and implement any emergency related interventions promptly, further pushing Nepali into more vulnerabilities and precarity. In relation to the response of the pandemic, this issue, along with a porous border and easy movement without proper records, made border management highly difficult for both the countries (Baniya, Bhattarai, Thapa \& Pradhan 2020; Nepal, Baniya \& Kshetri 2020). The government of Nepal has been considering a new provision for migration to India for employment, according to which it would make it mandatory for Nepali to receive permission from the concerned District Administration Office bordering with India, to migrate to work in India. The District Administration Office will make participation for necessary insurance and welfare funds. Provisions like this will help mitigate the lack of records and data, and will aid in better management of the cross border migration. 
Thirdly, the COVID-19 crisis calls for the need to shift towards a more responsive and resilient state. Government levels starting from the local level, who are actually in the forefront of the battle against the pandemic, up to the provincial and federal level must be responsible in developing short and medium term plans for social protection, recovery and integration of the migrant workers. This will require coordinated and comprehensive inter-governmental efforts in formulating plans and strategies. The plans and programmes of the federal and local governments need to be tailored to provide employment and enterprise opportunities in various sectors, as a part of sustainable integration within the country and to mitigate the adverse drivers of migration and vulnerabilities.

Fourth, the need for protection of Nepali migrants in India is further reinforced from the current experiences. It is therefore necessary that Nepal recognise migrants as one of the most vulnerable groups, and any crisis and relief plans should be built keeping them in mind. Former Prime Minister, Pushpa Kamal Dahal had announced that Nepali working in India as well as abroad will get an insurance of Rs 500,000 for deadly diseases, which can be claimed upto Rs 2,000,000 from the insurance service providers and a maximum of Rs 700,000 from Foreign Employment Promotion Board (Sedhai 2020). However, it was a political comment and was not included in the budget of Nepal.

Fifth, any future disputes regarding exploitation of Nepali migrant workers by employers such as non-payment of wages, denial of basic services including health shall be addressed through coordinated and available legal means. Moreover, the foreign policy and labour diplomacy of Nepal needs to consider addressing the risks of Nepali migrant workers being subjected to violation of human rights and indignity. Furthermore, there seems to be a gap in engagement with Nepali diaspora in India who could have been instrumental in supporting the GoN in helping migrants in distress and also facilitating their repatriation process.

Finally, although various national and international entities have been called upon on many occasions for due enforcement of international conventions related to protection of migrants and their rights, namely, the Protection of the Rights of All Migrant Workers and Members of their Families 1990, International Covenant on Civil and Political Rights (ICCPR), Charter of the United Nations, Universal Declaration of Human Rights (UDHR) and Global Compact for Migration (GCM), we can see that in the light of the recent events, these provisions came under brutal test, and as of the time of writing this paper, adherence to these norms and 
commitments have proven weak in the part of the governing bodies from both Nepal and India.

\section{CONCLUSION}

Migration to India was and is still an integral part of international migration for Nepal. Migrants are the most vulnerable group whose situation becomes more visible but precarious in the face of a sudden crisis. The onset of the coronavirus pandemic has put the already vulnerable Nepali migrants in India into a dire situation. The situation has been further exacerbated by the lack of legal instruments governing migration to India and most migrants' lack of protection and social security owing to their irregular status.

Sudden announcements of lockdowns, including domestic and international travel bans and border crossings led the migrants to be stranded and distressed. The return for many migrants has been marked with a perilous journey, and the harsh reality of being barred from entry to their own country and being stranded at the border for weeks. They have also faced ill-treatment and stigma, and face health hazards due to inadequate quarantine and other services. Furthermore, weeks of continued lockdown without effective aid provided by the government created an environment of anguish and fear, and depleted the food and income resources required for their subsistence. Not only that, inadequate quarantine and health services only increased the risk of infections and poor hygiene.

Nepali migrants, especially daily wage workers who generally have no savings, have had to bear the brunt of COVID-19 pandemic. To make matters worse, most of the daily wage workers have families with pregnant women, children, and elder parents. Female migrant workers who are pregnant themselves are in more complicated situations. Moreover, there is still uncertainty looming over the issues regarding repatriation of Nepali migrants from various Nepal-India border points. Although Nepali migrant workers in India were allowed entrance into Nepal with relaxed rules from both sides starting from end of April, the lack of prompt health facilities within Nepal, along with the absence of any financial safety net, exacerbated the situation. On top of this, many sections of the society criticized the government's delayed reaction as an evidence of incompetence and unpreparedness. Despite many migrant workers having survived the arduous journey from India to Nepal, it appears that they have fallen into the cracks of transnational bureaucratic hassle and sheer lack of unpreparedness of the outbreak among the two countries. More studies about the medium and long term impacts and its implications on wider 
socio-economic and political situations and international relations, will be necessary.

\section{ACKNOWLEDGEMENTS}

We would like to thank Bhimkala Limbu, Dogendra Tumsa, Manju Gurung, Binod Dulal and Ratna Kambang at Social Science Baha for their invaluable support in compilation of news articles. We are also sincerely grateful to the anonymous reviewers for their very insightful feedback on the article.

\section{REFERENCES}

Adhikari, J. \& Gurung, G. (2009). Migration, security and livelihoods: A case of migration between Nepal \& India. NIDS and NCCR Kathmandu, Nepal.

Akaha, T. (2018). International migration and human security and development in Mongolia. Mongolian Journal of International Affairs, 20: 45-70. https://doi.org/ 10.5564/ mjia.v20i0.1024.

Bauomy, J. (2020, March 6). COVID-19 and xenophobia: why outbreaks are often accompanied by racism. Euronews. https://www.euronews. com/2020/03/05/covid-19-and-xenophobia-why-outbreaks-areoften-accompanied-by-racism

Betts, A. (2011). The international politics of migration. St Antony's International Review, 6(2): 134-150.

Baniya, J., Bhattarai, S., Thapa, B. J. \& Pradhan, V. (2020). COVID-19 and Nepali labour migrants: impacts and responses. Kathmandu, Nepal: Centre for the Study of Labour and Mobility.

Commission on Human Security (2003). Human security now. Commission on Human Security New York, United States.

Geiger, M. (2020). Migration governance at the global level: intergovernmental organizations and environmental changeinduced migration. In: Tim Krieger, Diana Panke and Michael Pregernig (eds.) Environmental Conflicts, Migration and Governance. Bristol University Press, pp 157-175.

GoN (2020). Pandhraun yojana: Aarthik barsa 2076/77-2080/81. Government of Nepal Kathmandu, Nepal, p 328.

Guadagno, L. (2015). Reducing migrants'vulnerability to natural disasters through Disaster Risk Reduction measures: Including migrants in disaster prevention, preparedness, response and recovery efforts. Migrants in Countries in Crisis, Geneva, Switzerland. 
Ibrahim, M. (2005). The securitization of migration: A racial discourse. International Migration, 43(5): 163-187.

ILO (2020). Social protection responses to the COVID-19 crisis: country responses and policy considerations. International Labour Organization, Geneva, Switzerland.

IOM (2017). Addressing the Situation of Migrants in Countries in Crisis. International Organization for Migration, Geneva, Switzerland.

Kansakar, V. B. S. (2003). International migration and citizenship in Nepal. In: CBS, (ed.) Population Monograph of Nepal. Central Bureau of Statistics, pp. 85-119.

Kelly, B., \& Wadud, A. J. (2012). Asian labour migrants and humanitarian crises: Lessons from Libya. International Organization for Migration, no. 3.

Khatiwada, P. P. (2014). International migration and citizenship in Nepal. In: Esther Bayliss (ed.) Population Monograph of Nepal Volume I (Population Dynamics). Central Bureau of Statistics, pp 221-237.

Koser, K. (2010). Introduction: International migration and global governance. Global Governance, 16(3): 301-315.

Mawadza, A. (2008). The nexus between migration and human security Zimbabwean migrants in South Africa. Institute for Security Studies Papers, 162(12).

McCormack, S., Larsen, J. J. \& Husn, H. A. (2015). The other migrant crisis: Protecting migrant workers against exploitation in the Middle East and North Africa. International Organization for Migration Geneva, Switzerland.

MICIC (2016). Guidelines: To protect migrants in countries experiencing conflict or natural disaster. Migrants in Countries in Crisis Initiative, Geneva, Switzerland.

MoLESS (2020). Nepal labour migration report - 2020. Ministry of Labour, employment and Social Security Kathmandu, Nepal, p3.

Munck, R. (2008). Globalisation, governance and migration: An introduction. Third World Quarterly, 29(7): 1227-1246.

Nepal Rastra Bank (2020). Remittance status in Nepal (in Nepali). Nepal Rastra Bank Kathmandu, Nepal, p 2.

Nepal, R., Baniya, J. \& Kshetri, K. T. (2020). Kovid-19 mahamariko chapetama Nepali aaprabasi shramikko adhikaar: Addhyan pratibedan: Study report. Kathmandu, Nepal: National Human Rights Commission. 
Piper, N. (2017). Global governance of labour migration: From 'management' of migration to an integrated rights-based approach. In: Peter Drahos (ed.) Regulatory Theory. ANU Press, Australian National University, pp 375-392.

PNCC (2020). Brief report on the cases received in COVID-19 online form: An urgent call for action to the government for the protection of Nepalese migrant workers during the pandemic of COVID-19. Pravasi Nepali Coordination Committee, Kathmandu, Nepal.

Ratha, D. K., De, S., Kim, E. J., Plaza, S., Seshan, G. K. \& Yameogo, N. D. (2020). Migration and development brief 32: COVID-19 crisis through a migration lens. World Bank Washington DC, United States, p31.

Sammadar, R. (2020). Introduction: Borders of an epidemic. In: Ranabir Samaddar (ed.) Borders of an epidemic: Covid-19 and migrant workers. Mahanirban Calcutta Research Group, pp 1-23.

Sharma, S., \& Thapa, D. (2013). Taken for granted: Nepali migration to India. Centre for the Study of Labour and Mobility Kathmandu, Nepal, p 1.

Sedhai, Roshan, (2020, January 24). PM announces to double insurance cover of migrant workers. The Kathmandu Post. https://kathmandupost. com/national/2017/01/24/pm-announces-to-double-insurancecover-of-migrant-workers.

Sijapati, A. (2020, May 4). Nepal's muslims face stigma after COVID-19 tests. Nepali Times. https://www.nepalitimes.com/banner/nepalsmuslims-face-stigma-after-covid-19-tests/

Song, J. (2015). Redefining human security for vulnerable migrants in East Asia. Journal on Human Security, 11(1): 45-56.

UNDP (1994). Human Development Report 1994: New dimensions of human security technical report. United Nations Development Program, New York, United States, p 24.

Wohlfeld, M. (2014). Is migration a security issue? In: Omar Grech \& Monika Wohlfeld (eds.) Migration in the Mediterranean: human rights, security and development perspectives. MEDAC, University of Malta, pp 61-77. 